\title{
Cutting the Umbilical Cord: Patriarchy and the Family Metaphor in Turgenev's Virgin Soil
}

Katya Jordan

Brigham Young University

\begin{abstract}
:
Negatively reviewed by readers from both ends of the political spectrum, Ivan

Turgenev's final novel, Virgin Soil (1877), explores the nature of patriarchy within the context of the particular kind of populism (Narodnichestvo) that swept across the European part of Russia in the 1870s. In this novel, Turgenev continues to explore the theme of fractured father-son relationships as he investigates the long-standing tradition of viewing the Russian tsar as a father to his people. Within the framework of this family metaphor, which is often used in political discourse, Turgenev conceptualizes Russian radical intelligentsia as a natural son of an enlightened father. Educated and restless youth represent a logical, albeit unexpected, outcome of Tsar Peter's reforms that were intended to replace family ties with bureaucratic ties and to give opportunities for advancement to the non-noble. As an illegitimate child, however, the intelligentsia does not fit into the official state or family structure and acts as an interested yet annoying outsider. While drawing on the scholarship of Stephen Lovell and other social historians who explore the problem of genealogical and generational self-identification, this examination of Turgenev's oeuvre provides new legibilities of the family metaphor that lies at the core of Russian political discourse.

Keywords:

Turgenev, the family metaphor, patriarchy, fatherlessness, intelligentsia.

\section{Biographical Note}

Dr. Katya Jordan is an Assistant Professor of Russian at Brigham Young University, where she has been teaching since 2015. She received her Ph.D. and M.A. degrees in Slavic Languages and Literatures from the University of Virginia, and a B.A. in English from the University of Utah. She also studied linguistics and translation at Chelyabinsk State University in Russia. Her research interests lie primarily in the area of 19th-century Russian literature and culture, comprising such issues as female silence, ekphrasis, and iconicity. She has published articles on Pushkin, Dostoevsky,_Mamin-Sibiriak, Ilichevsky, and other topics. Her current research is devoted to women's literary periodicals that were published in late Imperial Russia.
\end{abstract}




\section{Cutting the umbilical cord: patriarchy and the family metaphor in Turgenev's Virgin Soil}

\section{Introduction}

Anticipating the reaction of both conservative and progressive readers to his latest novel, in November 1876 Ivan Turgenev wrote to a friend, 'There's absolutely no doubt that if for Fathers and Children I was beaten with sticks, for Virgin Soil I will be pummeled with logsand from both sides, too.' ${ }^{1}$ Of the six novels that Turgenev wrote in the course of his literary career, Virgin Soil (1877) may be considered the 'most political' as it turns the readers' attention to the wave of a particular kind of populism (Narodnichestvo) that swept across the European part of Russia in the $1870 \mathrm{~s}^{2}$ At the same time, the novel continues to explore the theme of fractured father-son relationships, taken up by Turgenev in his earlier works. Drawing on the scholarship of Stephen Lovell and other social historians who explore the problem of genealogical and generational self-identification, this paper will argue that in his final novel, Virgin Soil, Turgenev metaphorically presents the Russian intelligentsia as illegitimate children of the Russian tsar who attempts to play the role of an enlightened patriarch. This examination of Turgenev's oeuvre provides new legibilities of the family metaphor that lies at the core of Russian political discourse.

\section{The Family Concept and Metaphor}

Contemporary Russian sociologists define a family as 'a social union' that 'consists of people and their mutual relations' who are 'linked together by a common way of life, mutual moral responsibility and assistance.' ${ }^{3}$ Beyond its immediate concerns, a family 'constitutes not only a basic unit of society, but a basis for the metaphors that shape today's socio-political value 
orientations' (Zritneva 1). George Lakoff and Mark Johnson explain that when most ordinary notions acquire metaphorical meanings they begin to shape moral values and judgments prevalent within a group. ${ }^{4}$ Thus, '[t]he concepts that govern our thought are not just matters of the intellect. They also govern our everyday functioning, down to the most mundane details' (Lakoff and Johnson 22). Because it accompanies most individuals throughout their whole life, the concept of the family naturally lends itself to being heavily metaphorized and endowed with certain socio-political weight.

Boris Mironov, whose Social History of Imperial Russia covers a period between 1700 and 1917, examines the family concept in a broad historical perspective, demonstrating that family relations and social relations at large 'tend to intertwine and reinforce one another,' making the family a useful tool in studying a society as a whole. ${ }^{5}$ By the time of Turgenev's writing, both the Russian family the Russian state could be considered nothing if not patriarchal. ${ }^{6}$ In the present analysis, I agree with Susan Morrissey who defines patriarchy as 'relations of governance presided over by a "father" who dominates over all of his subjects—-both male and female—indiscriminately. ${ }^{7}$ She explains:

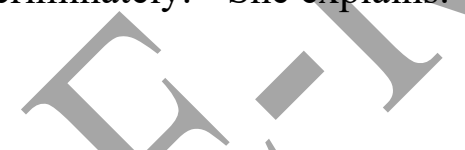

While patriarchy is built upon a concept of gender domination, to restrict its use to instances of male rule over females addresses neither the varieties of female experience as mediated, for example, by class nor other (gendered) relations of domination and submission. In its broader sense, therefore, the term 'patriarchy' accentuates the analogous structures of power in a society— between the tsar and his servitors, the lord and his serfs, the husband and his wife, the master and his apprentice, the officer and his soldiers, and so forth. (Morrissey 24) ${ }^{8}$ 
The characterization of the Russian tsar as a father of his people is propagated in many venues. ${ }^{9}$ The folk proverb 'Without a tsar, the people is an orphan and the land is a widow' [Бе3 царя народ сирота, земля вдова] not only sums up the tremendously important, stabilizing role that a Russian ruler plays in the society he governs, but suggests a level of emotional intimacy ordinarily expected within a nuclear family. ${ }^{10}$ The appellation 'Our tsar! Father of the people!' [Царь ты наш! отец народа!] from Alexander Pushkin's fictional Tale of the Golden Cockerel (1834) is echoed in open letters to the emperor that were published in newspapers throughout the nineteenth century and reflects the emotional connection that the vast majority of the population of the Russian empire felt towards the tsar. ${ }^{11}$ Grigorii Rasputin appeals to the same sentiment in the letter he sent to Nicholas II from Siberia, pleading with the monarch to not get entangled in the conflict that later will be known as World War I: You are the tsar, the father to the people, do not suffer the insane to triumph' [Ты царь отец народа не попусти безумным торжествовать..$^{12}$ After Nicholas II, who considered himself 'a master of the Russian land,' was brutally removed from the pedestal by the Bolsheviks, the new regime made use of the same metaphors in the ensuing decades. ${ }^{13}$ The patriarchal socio-political outlook easily survived throughout the Soviet period, when Communist leaders compared the party to a family 'with themselves in the position of the parent. ${ }^{14}$ This sentiment is still expressed by some Russian citizens towards Russia's president today. ${ }^{15}$

In Turgenev's lifetime, the patriarchal mindset overcame even the cultural rift between the nobility and the serfs that had formed in the wake of Peter the Great's far-reaching reforms. ${ }^{16}$ The most traditional and conservative segment of Russia's population, its peasant class, viewer family not only in biological, but also in economic terms, which led the Russian zemstvo statisticians to defined a peasant family unit as 'a number of people constantly eating at one table 
or having eaten from one pot. ${ }^{17}$ Mironov notes that prior to 1861 , 'the large, multigenerational, patriarchal household' functioned 'according to an age- and gender-based division of labor' and in essence represented 'an absolutist state in microcosm' (Mironov and Eklov 145). At the same time, Hubbs states, the Russian nobility too 'deferred to the will of the autocrat' and 'saw in the role of the father the need for domination and self-assertion over the land, the peasantry, and a family structure' (Hubbs 166). Thus, personalized authority was the chief governing force both on the level of an isolated patriarchal household and on the level of the state as a whole. ${ }^{18}$

\section{From Genealogy to Generation}

Despite the strong sense of belonging that the Russian patriarchal society fostered in its members, in the second half of the nineteenth century, and especially in the 1860s, Russia experienced what Lovell identifies as 'one of the most acute recorded cases of generational rebellion' and 'the first of its kind anywhere in Europe.' ${ }^{19}$ At this time, activists from among the student population incessantly called for 'the burning of one's ships,' thus symbolically 'severing the umbilical cord' and declaring independence from the fathers. ${ }^{20}$ The intergenerational conflict that is so famously, albeit inconclusively, described in Fathers and Sons reflects the fissures that were becoming apparent in the foundation of the patriarchal state. On closer examination, however, if one were to read all of Turgenev's major works as the author suggested, 'one after another' [сподряд], one will notice the consistent feature that appears in each of one them-young men estranged from their biological fathers. ${ }^{21}$

Turgenev's six novels constitute one coherent fictional metanarrative centered around one theme. Fatherless children —illegitimate and/or orphaned sons - appear in each of the six novels and represent those within Russian society whose social status is precarious precisely 
because their position within their own families is uncertain. Heroines too, though never illegitimate, are estranged from their fathers. In Turgenev's first published novel, Rudin (1856), the father of the eponymous protagonist dies soon after his birth, and Rudin is raised by a widowed mother. In The Nest of Gentry (1859), Lavretsky, the protagonist, is born from parents in a morganatic union between a landowner and a serf girl, is abandoned by the father for a time, and loses his mother at a young age. The protagonist of On the Eve (1859-60), Insarov, is of legitimate birth, but is orphaned at the age of eight. In Fathers and Children (1862), the warmth between one of the fathers of the title, Nikolay Kirsanov, and his older son, Arkady, is more of an exception than a rule; nevertheless, Arkady's half-brother, Mitya, is illegitimate, and although Nikolay later marries Mitya's mother, Fenechka, from a legal standpoint, Mitya will remain illegitimate and will have no claim on his father's property or title. ${ }^{22}$ Although the protagonist of Smoke (1867) is a legitimate son of a still living father, the father of his competitor, officer Ratmirov, is a natural son of a nobleman. Finally, in Virgin Soil (1877), the protagonist, Nezhdanov, is a natural son of a nobleman.

Twenty-one years separate Rudin and Virgin Soil, putting the children in the first novel in the position of much older siblings, if not fathers, in the last, yet the conflict remains essentially the same: noble fathers are failing their children emotionally, financially, or in other ways, while fatherless sons - born out of wedlock, orphaned before entering adulthood, or both—struggle to find their place in life. ${ }^{23}$ Notably, before these 'superfluous men' were described in fiction, a similar pattern of failed father-son relationships unfolded in real life:

A high proportion of the homes from which the leading intelligenty came offered neither the love nor the stability needed for the normal development of happy human beings. 
Again and again as we glance through the biographies of the intelligentsia, we find that the child was illegitimate (Pnin, Zhukovsky, Polezhaev, Herzen), or early lost one or both parents and was brought up by remoter relations or servants (Chaadayev, Lermontov, Tolstoy, Kropotkin), or grew up in a home shadowed by the indifference or unhappy temperaments of one or both parents (Pushkin, Belinsky, Turgenev, Dostoevsky). ${ }^{24}$

The reality that was nourishing the imaginations of Russian fiction writers and ideologues was rarely carefree. More than half of the individuals listed by Seely were either threatened with or actually spent time in prison or exile for anti-government sentiment or activities. Among them, the earliest birth date belongs to the poet Ivan Petrovich Pnin (b. 1773), and the latest death date belongs to the anarchist and revolutionary Pyotr Alexeevich Kropotkin (d. 1921), spanning a century and a half of what appears to be an ideological stand-off between the bureaucratic state and the intelligentsia, couched in familial terms. ${ }^{25}$

Lovell puts forth the idea that although any member of a society can conceptualize his or her 'location in time' in one of two ways - genealogy or generation - these two notions are not mutually exclusive $(567,590)$. Whereas the former 'takes its bearings from lines of family descent,' 'provides a vertical sense of belonging that defines the people of the present in terms of their ancestors,' and 'concentrates on succession,' the latter is customarily measured by 'cohorts of people born at approximately the same time,' 'emphasizes simultaneity,' and 'potentially transcends kin' (Lovell 567). Nevertheless, one can see oneself simultaneously as a descendant from a genealogical line and a coeval to like-minded peers, which ultimately was the intelligentsia's method of dual self-conception (Lovell 590). It is this dual self-conception that leads Turgenev's fatherless sons to their demise. 


\section{Fatherless Children}

In Turgenev's Virgin Soil, the protagonist, Alexei Nezhdanov, attempts to define his identity through his interaction with a new generation of political activists, yet his connection to his genealogy does not allow him to fully embrace their political cause. Unable to overcome this contradiction, he chooses to end his own life, demonstrating the impossibility of overcoming both the external conflict (between political patriarchy and individual citizens) and his own internal conflict (between his genealogical connection to the ruling class and his desire to be accepted by the masses).

Alexei Nezhdanov's birth is a result of an extramarital liaison of Prince G. and the young woman, Nastya, who worked in the prince's home as a governess. The father did not anticipate Alexei's birth and therefore gave him a last name that means 'the unexpected one. ${ }^{26}$ Nezhdanov's mother died in childbirth, leaving Alexei an orphan. Although little is known about Prince G., the reader is informed that 'thanks to father's kindness' Nezhdanov was able to obtain a university education and now receives a pension; however, as Nezhdanov's half-brother notes, Alexei has 'gone completely mad; he's some sort of republican and we don't receive him... Il est impossible’ (19).

Because of his education, Nezhdanov is qualified to engage in intellectual work or in state service; however, possibilities for the former are rather limited, and engaging in the latter would be contrary to his political convictions. Additionally, he does not fit into an archaic rank system of civil or military ranks, and as an illegitimate son, he will never be equal to his halfsiblings. Desiring to be of service to the common folk, he joins an underground circle of the narodniks, but that does not resolve the question of his identity. When Nezhdanov refuses to 
accept financial help from Paklin, a fellow activist, he is called out on neglecting the common cause due to his class origin:

'Well, brother,' said Paklin, 'I can see that you may be a revolutionary, but you're no democrat.'

'Come straight out with it—I'm an aristocrat.'

'You are indeed an aristocrat- - to a certain extent.'

Nezhdanov gave a forced laugh.

'That is, you wish to allude to the fact that $\mathrm{Ym}$ an illegitimate son. Your labours are in vain my friend ... I don't need you to remind me of the fact? (14)

Even without Paklin's observation that one's lineage colors one's political convictions Nezhdanov is already painfully aware of the burden his kinship presents to him. Soon after the conversation with Paklin, Nezhdanov goes to a theatre where he takes a seat in a front row. At first he intended to buy a cheaper ticket for the stalls, but just as he was ready to pay, he heard an officer's voice oyer his head: "“He”- that is Nezhdanov——will probably need change, but I don't. So please give me a front-row ticket as quick as you can—I'm in a hurry!"' (18). Nezhdanov, whether to prove his own ability or to satisfy his pride, hands the clerk three roubles and buys himself a much more expensive ticket. When the play starts, he finds himself sitting between 'a general emblazoned with stars' and a very elegant gentleman who later turns out to be Privy Counsellor Sipyagin (18). Nezhdanov is uncomfortable in his surroundings. He sits 'motionless and awkward, in his wide comfortable seat, like some sort of pariah. His heart [is] full of bitterness, shame and revulsion,' and he doesn't even enjoy the play, which happens to be 
Alexander Ostrovsky's comedy Don't Sit in Another Man's Sledge, designed to ridicule the society in which ranks and wealth determine characters' treatment of each other (18). ${ }^{27}$

Sipyaging offers Nezhdanov a position of a tutor to his son for the duration of the summer, which Nezhdanov accepts for two reasons. One, the pension provided by Prince G. is not big enough to support Nezhdanov in his underground activities, and two, Nezhdanov sees it as an opportunity to rest at Sipyagin's country estate until the fall as he prepares for the actual work of spreading propaganda among provincial peasants and factory workers. Sipyagin, in his turn, attempts to position himself as an enlightened patriarch. He is a state functionary, loyal to the tsar, but he recommends himself to Nezhdanov 'as a man of liberal, progressive convictions' that do not contradict those of Nezhdanov. Later Sipyagin admits to being 'to some degree a Slavophile, and while he likes Nezhdanov's 'youthful ardour,' he concedes that his wife's views 'are perhaps closer' to Nezhdanov's than to his own; but that is 'to be expected: she's younger than me!' Sipyagin adds $(21,47)$.

At the estate, Nezhdanov meets Sipyagin's niece, Marianna, who is an orphan and lives there as her uncle's ward. When the ideological tension becomes unbearable and Nezhdanov finally leaves Sipyagin's home, Marianna insists on going with him more on ideological grounds than on romantic ones. ${ }^{28}$ Evidently, Mrs. Sipyagin, Marianna, and Nezhdanov belong to the same generation, which makes it easier for them to be open to the new ideas, yet in the end of these three characters only Marianna fully embraces Narodnichestvo.

This unique brand of Russian populism was o the rise in the early and mid-1870s. Described as an 'incompletely integrated complex of ideas [that] had as its core an ethically and emotionally motivated agrarian Socialism,' Narodnichesvto was especially appealing to young 
raznochintsy like Nezhdanov. ${ }^{29}$ Avram Yarmolinsky explains what Narodnichestvo is in the following terms:

The term, which gained currency in the 'seventies, suggests the important part played in this ideology by the concept of narod (people), in the sense of demos, the broad social base, the great body of manual workers, specifically the peasantry. With concern for the material welfare of the masses went a mystique which surrounded 'the people' with a halo. Some viewed them as potentially or actually an irresistible historical force; others as the repository of all the virtues, the sole source of spiritual energy and thus the hope of the world. $(170-1)^{30}$

Those who embraced Narodnichestvo had lost any hope of convincing the government of the need for social reform. The activists believed that if they educate the masses by exposing them to modern ideas, in time these masses will either engage in revolutionary action themselves or will accept radical changes brought about by others (Elizabeth Wood 359). For those who, like Nezhdanov, could not find a place for themselves within an established system, the idea of Going to the People becames a last resort.

Turgenev wrote Virgin Soil simultaneously with the formation and the disintegration of the Going to the People movement as the narodniki court trials were taking place. He first mentioned his idea for Virgin Soil in July 1870, before the movement picked up speed, but put it aside for some time. When he returned to it in 1876 , he wrote the entire novel in the course of five months and 25 days and published it in the first two issues of the 1877 volume of The Herald of Europe (Turgenev, PSS 12: 478). The year 1873 marked the high point for the 
narodniki, which was followed by 'the mad summer' of 1874, as Pyotr Kropotkin calls it, when hundreds of people, perhaps even between two and three thousand, were on the march (Feuer 98, Yarmolinsky 189). This movement, of course, did not go unnoticed by the police. Overall, between 1873 and $1876,1,611$ political suspects $(85 \%$ men) were questioned, 557 of this number were then dismissed, 450 were placed under police surveillance, 79 were deported to distant parts of the Empire, and 525 were held for court trial (Yarmolinsky 205). Later the same year, the majority of the narodniki court trials took place. After four years of investigation, The Great Trial, or The Trial of 193, which according to some estimates initially involved 3,800 people including witnesses, took place between October 18, 1877 and January 23, 1878 (207). ${ }^{31}$ Cases of insanity and death in prison were frequent, many of which were caused by solitary confinement (Yarmolinsky 207, Soburova and Eklof 120-122, 152-6). In other words, despite the novel's artistic qualities and fictional character, Turgenev was writing Virgin Soil almost in the form of a current events report, and Nezhdanov's suicide at the end of the novel is not farfetched considering the actual flow of events.

The narodniki placed an especially high value on two things that most of them possessed: youth and simplicity. Indeed, their youth was a mark of distinction. As Sergei Kovalik, one of the participants of the movement, writes in his memoirs, '[i]n the 1870 s, eschewing the participation of an older generation inclined to compromise, the youth set out all alone, to resolve all (of Russia's) cursed questions which gave humanity no respite. This generation resolved to take upon its own shoulders the entire burden of rejuvenating the world. ${ }^{32}$ Youth was a sign of hope, a new beginning, a possibility of a renewal for the society as a whole.

At the same time, breaking away both from their biological fathers and from the bureaucratic state, young people — both men and women — strived to simplify their own lifestyle 
[опроститься]. One reason for this was their disdain of all material excess in the face of the common people's plight. While staying in the Russian countryside in the summer of 1872 , Turgenev encountered a girl of noble birth who had embraced the simple lifestyle and was hired to work in the kitchen 'in order to come closer to the simple folk and to experience its life firsthand' [чтобы сблизиться с простым народом и на себе испытать его жизнь] (Furgenev, PSS 12: 481). Like this girl, Marianna in Virgin Soil is also eager to embrace the simple life and even insists that she should not be called 'miss' [барышня] or be given a servant; instead, she would prefer 'not a maid but a helper, American-style' (Turgenev, Virgin Soil 175).

At the root of this transformation lies the concept of a 'repentant nobleman,' when young people from the privileged class attempted to expiate the sins of their serf-owning predecessors. ${ }^{33}$ Yet the more important reason for 'simplification' was the belief that by doing so the young activists would be able to break down the barriers between themselves and the common folk. This 'simplification' was often the first step towards becoming actively engaged in revolutionary activity, and this symbolic laying aside of the clothes of one class in order to put on peasant garb was the first symbolic step of 'a spiritual adyenture. ${ }^{34}$ When Nezhdanov prepares to go to the people, he disguises himself so well that even Marianna cannot recognize him at first. 'He was wearing a threadbare yellowish nankeen kaftan with minuscule buttons and a high waist; he had done his hair Russian-style, with a straight parting; he had wrapped a blue muffler round his neck; in his hand he held a cap with a broken peak; and on his feet he had unpolished calfskin boots' (Turgenev, Virgin Soil 175, 186). When Marianna finally recognizes him, she observes, 'You look like some sort of municipal shopkeeper, a pedlar or a retired house serf' (187). But this attempt at a transformation does not come easily to Nezhdanov. Despite all his efforts, the change is superficial, and he feels out of place: 'in his heart of hearts [he] was annoyed and 
embarrassed; so embarrassed was he that he kept running the outstretched fingers of both hands over his chest, as if he were brushing himself down' (187). He confesses to Marianna: 'I would note in parentheses that this doesn't do much for my self-esteem' (187).

The activists also changed their usual apparel for practical reasons. Disguised as the common folk, narodniki hoped to become less visible to the police. Nonetheless, this method was not fool-proof, for often the people they preached to turned them over to the police as suspicious provocateurs. Nezhdanov avoids an arrest, but has to go through a more painful experience when he realizes that he has failed as a propagandist and is now completely disillusioned in the very cause of Narodnichestvo. After another unsuccessful attempt at talking to factory workers, Nezhdanov confides in Marianna, Tno longer believe in the cause which united us, for which we left that house together and towards which I, to tell the truth, was already growing cool when your fire warmed and ignited me; I no longer believe in it, no longer' (242). Nezhdanov has no place in his father's noble family or in Sipyagin's home, but neither does he have a place among the simple people whom he wishes to serve. Ruth Perry explains that traditionally, 'the rules of kinship determine both the obligations of the individual to his/her kin group or family in the broadest sense, and, reciprocally, the claims of an individual on the resources of the kin group. ${ }^{35}$ These include such things as 'absolute property rights and use rights, productive labor and care-giving [...] political power, and the social position, rank, or reputation of one descent group vis-à-vis other descent groups' (Perry 4). Nezhdanov, on the one hand, benefits from the educational opportunities that his father provides for him and from the employment in Sipyagin's home, but pays both of them back by rejecting their conservative values. At the same time, as he takes upon himself an obligation to serve the masses and to give of his abundance, he is rejected by the folk and runs the risk of being punished by the state. 
In V.A. Nedzvetsky's estimate, of all Turgenev's characters Nezhdanov comes to the revolutionary movement the closest, but his disenchantment and ultimate failure is caused by his inability to 'forget about himself' and live solely for others. ${ }^{36}$ But perhaps Nezhdanov cannot forget himself because he lacks a clear understanding of who he is in the first place, and this lack of a clear understanding of his personal identity is caused by his problematic relationships with his father and by his status of an illegitimate son. Turgenev writes about Nezhdanov:

The false position in which he had been placed since birth had developed touchinesss and irritability in him, but his innate magnanimity did not allow him to become suspicious or mistrusting. The same false position explained the clashing contradictions in Nezhdanov's character. Neat to the point of punctiliousness, horribly squeamish, he forced himself to be cynical and coarse in his speech. An idealist by nature, passionate, chaste, bold and timid simultaneousty, he was ashamed of his timidity and chasteness as of something dishonourable, and considered his duty to laugh at ideals. He had a tender heart and shunned people; he angered easily—and never remembered the anger. He was indignant with his father for launching him 'into aesthetics'; he openly, for all to see, occupied himself solely with political and social questions, professed the most extreme of opinions (they were no mere phrases for him), but secretly he reveled in art, poetry and beauty in all their manifestations, even writing verses himself... Nothing so offended and outraged Nezhdanov as the slightest allusion to his poetic efforts, to this, so he imagined unforgivable weakness... His friends liked him: they were attracted by his inner rectitude, goodness and purity. But Nezhdanov was not born under a lucky star; life was 
not easy for him. He himself was profoundly aware of this and felt himself isolated, despite the devotion of his friends. (Turgenev, Virgin Soil 26)

Nezhdanov's painful self-awareness competes with his unclear sense of personal identity. In the eyes of everyone in his father's social circle, were Nezhdanov ever try to elevate himself to their level, he would forever remain an impostor. Yet when Nezhdanov attempts to go to the people and serve the oppressed masses, he sees that there too he is not accepted. The conflict that Nezhdanov faces is intensified by the fact that in Imperial Russia one's loyalty to the family and one's loyalty to the bureaucracy were inseparable. Lovell points out a paradox:

the Russian state was both modernizing and archaicizing. On the one hand, it wanted to tear noble sons away from their clan and to extract from them devoted service to a modern bureaucratic war-making and tax-raising machine. On the other hand, like all other absolutist states, it made use of handy patriarchal rhetoric [where] the head of the state was presented as a domineering yet benevolent father. (570-1)

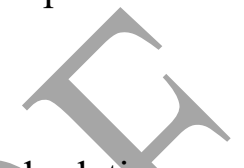

As blood relations are replaced with bureaucratic connections, Turgenev's orphaned and illegitimate male characters are lost within a system that offers no warmth yet demands loyalty. in Virgin Soil, Nezhdanov resolves this tension by committing suicide, thus completely removing himself both from his father's biological family that has no place for him and from a future family that he and Marianna could potentially create: he severs both the genealogical and the generational tie. 


\section{Political Underpinnings of the family Metaphor}

Both in its literal and its metaphorical sense, the family has long been one of the key tools for conceptualizing the Russian socio-political model, especially in its patriarchal form. Although patriarchy has been invoked by various religious and civic governments as far back as Ancient Greece, it proved to be particularly important for Russia where, to use Paul Conner's characterization, the state can lay claim to its own segment in 'a fortress of father metaphors' in its socio-political discourse. ${ }^{37}$ However strong this fortress may be, it is not entirely impenetrable, and Peter I, who through his reforms and construction projects famously cut 'a window on Europe,' inadvertently created a breeding ground for a new kind of citizens, the Russian intelligentsia.

Members of the intelligentsia identified themselves as such based on not only their Western education, but on their moral impulse to improve Russian society as a whole by serving the common folk and by overthrowing the imperial regime. ${ }^{38}$ When the term 'intelligentsia' first came into use in the $1860 \mathrm{~s}$, its definitions included such notions as 'educated people,' 'a group embodying Russian national consciousness,' and 'Russian radicals. ${ }^{39}$ With time, members of the intelligentsia took upon themselves the responsibility to act as a civic conscience and to provide moral guidance to their fellow-citizens. ${ }^{40}$ Albeit diverse in their socioeconomic backgrounds and convictions, over time members of the intelligentsia turned into the government's severest critics. Sergii Bulgakov, an early twentieth-century philosopher, economist, Russian Orthodox theologian, and himself a lustrous representative of the intelligentsia, explains: 
The soul of intelligentsia, of this creation of Peter's, is also a key to the future destiny of Russian statehood and its civil society. For better or worse, the fate of Peter's Russia is in the hands of intelligentsia, however persecuted and victimized it is, however weak and even powerless it might seem at the moment. It is that window, cut by Peter, through which the Western air comes to us, both life-giving and poisonous. ${ }^{41}$

Because neither statehood nor the civil society is possible without a recognition of individual rights, members of the intelligentsia both preached, and in many cases embodied, what Petr Struve calls 'self-alienation' [отщепенство], 'an estrangement from state structures and hostility towards the state. ${ }^{, 42}$ In pre-Petrine Russia, positions in military or civil service to the prince were doled out on the basis of the rank of one's predecessor. ${ }^{43}$ Following Peter's reforms of the early 1700s, individual members of noble families could no longer rely on the achievements of their forebears in obtaining social prestige and material possessions. Peter's investment in the bureaucracy and in the Table of Ranks as a principal tool used in organizing Russia's socio-political hierarchy and its system of rewards in effect replaced family ties with bureaucratic ties ${ }^{44}$ Ranks were now distributed based on a subject's personal achievements in service to the state and not on his blood kinship (Raeff, Origins of the Russian Intelligentsia 38$41)^{45}$

By the mid-1800s, this transformation led to an ideological division with the Slavophiles on one side, linking familial attachment to religious piety and love for one's own home and native land, and Westernizers on the other, rejecting all of these values in the name of individualism and dialectical reasoning. ${ }^{46}$ Examining in retrospect the work of the Slavophiles and the arguments put forth by Aleksei Khomiakov as the chiefest among them, the philosopher 
Nikolai Berdiaev, a Russian political and religious philosopher, indicted the Slavophiles for idealizing all civic relations in Russia and seeing them as ones based on a parent-child model:

The tsar treats his people as a father treats his children. The relationships between the regime and the people are patriarchal and only as such can they be recognized as good and sacred $[\ldots]$ The Russian people is familial and patriarchal for the most part; it loves not the state, but the family; it wants to live in a big family, treats the tsar like a father, and does not tolerate the state mechanism. ${ }^{47}$

What Turgenev's Virgin Soil presents to its readers, therefore, is a masterful study of two conflicting dispositions within one person - of hostility and of loyalty. On the one hand, as a member of the intelligentsia, the protagonist must be and is critical of the state authority and of the status quo. He resents both the state and the people, who represent it, and he attempts to alienate himself from all of it. On the other hand, as his father's son, albeit illegitimate and unexpected, he knows that his connection to the noble class transcends mere blood kinship. Prince G.'s wealth and concern for his natural son's wellbeing caused him to make provisions for Nezhdanoy's education and financial support. In fact, they have made Nezhdanov the person that he is.

It is this unresolved contradiction that caused Turgenev to think that neither progressive, nor conservative readers would in the end approve the narrative, and the author was proven right. The first half of the novel appeared in the January 1877 issue of The Herald of Europe, and a vast majority of the reviews that appeared in the ten days following the publication were negative. ${ }^{48}$ The government-sponsored newspaper The Voice (Golos) published a review, in 
which G. A. Larosh, the music critic, stated that Turgenev in Virgin Soil is merely repeating his old themes: neither do the underground activists depicted in the novel invoke 'any kind of artistic compassion' towards themselves, nor do they add even 'one iota' to the body of knowledge 'about peculiarities of this world that was brought to us by works of other fiction writers' (Lukina 24). ${ }^{49}$ In New Time, a liberal newspaper, the critic V.P. Burenin essentially repeated Larosh's main point about Tugenev repeating himself (Lukina 25). ${ }^{50}$ And the unabashedly conservative newspaper, Citizen (Grazdanin), published editorial remarks of V.P.Meshchersky, in which Turgenev was accused of creating a merely superficial verbal portrait of the activists devoid of any warmth of feeling towards them (27). When the second part of the novel was published, Meshchersky called the whole work 'abomination' and 'filth.' 51

\section{Conclusion}

The nuclear patriarchal family is frequently employed as a metaphor for conceptualizing socio-political relationships within a culture. Russia constitutes a prime example of this trend. While in literary fiction in general, children tend to personify tenacity and continuity, each one of Turgenev's major works in one way or another touches upon the theme of broken father-son relationships (Bocharov 20). In Virgin Soil specifically, Turgenev shows the price at which this sort of tenacity is developed and the problems that arise when this kind of continuity is not possible.

The family metaphor in Turgenev's novel Virgin Soil serves as a tool for understanding the political relations between the tsar and the people in Russia of the 1870s, when the Narodniki movement was on the rise. The broken relationship between the protagonist and his biological father and with the people of his father's social milieau is symbolic of the intelligentsia's 
inability to find common ground with the tsar and his bureaucracy. Within this framework, the intelligentsia plays the role of a natural son in two senses. One, it represents a logical, albeit unforeseen and unexpected, outcome of Peter's reforms that were intended to replace family ties with bureaucratic ties and to give opportunities for advancement to the non-noble. Two, the intelligentsia, like an illegitimate child, does not fit into the official state or family structure and acts as an interested yet annoying outsider.

A large portion of the radical intelligentsia comprised raznochintsy, or people of diverse ranks and sometimes of no rank at all. Those of noble birth who privileged their own ideological reasoning over family ties may be referred to as 'repentant nobles.' For these people, the conflict between a 'vertical' or 'genealogical' self-perception (linked to one's place within a family clan) and the 'cohort thinking' (and allegiance to one's chosen generation) was especially difficult to reconcile (Lovell 567). For them, Narodnichestvo and especially the Going to the People movement became a means of finding meaning in life: while solving society's problems, the activists had an opportunity to overcome their own identity crisis caused by their rejection of their genealogical family and their fathers' authority. Turgenev also shows that those among the fathers' generation who at times attempt to play the part of an enlightened patriarch do so more out of fashion than out of conviction.

Desirous of more effective sociopolitical reforms and always standing in opposition to the authorities, yet never able to reason with the father/tsar, young activists and members of the intelligentsia turn to the 'younger' brothers, the uneducated worker/peasant masses, only to get rejected. The latter's faith in and loyalty to the tsar is greater than their trust towards young people who pretend to be like them. For those activists who are honest with themselves, this element of pretense is also undeniable. At the same time, because of their upbringing and the 
opportunities that their lineage and socioeconomic situation afford them, members of the intelligentsia cannot easily deny their own privileged position. For Turgenev, this conflict is insurmountable.

${ }^{1}$ A.G. Ostrovskii, Turgenev v zapisiakh sovremennikov: Vospominaniia. Pis'ma, Dnevniki. (Moskva, 1999): 271. All translations from Russian in this article are my own unless noted otherwise.

2 Patrick Waddington, 'Turgenev and the Translator of "Virgin Soil."' New Zealand Slavonic Journal, no. 3 (1977), 35-76.

${ }^{3}$ Elena Zritneva, Sotsiologiia sem 'i: uchebnoe posobie (Moskva, 2017): 1. In this union, the key factors are marriage, blood kinship, common living, and a shared budget.

${ }^{4}$ George Lakoff and Mark Johnson, Metaphors we Live by (Chicago, 1980): 3.

${ }^{5}$ Boris Nikolaevich Mironov and Ben Eklof, The Social History of Imperial Russia, 1700-1917, vol. 1 (Boulder, 2000): 144-5.

${ }^{6}$ Although one can argue that the concept of a father figure in Russian culture appears as a side effect of 'the gradual establishment of a despotic state' in an otherwise matriarchal society. See Joanna Hubbs, Mother Russia: The Feminine Myth in Russian Culture (Bloomington, 1988): 166.

${ }^{7}$ Susan Morrissey, 'Patriarchy on Trial: Suicide, Discipline, and Goyernance in Imperial Russia,' The Journal of Modern History 75, no. 1 (2003): 23-58.

${ }^{8}$ This view is contrasted by, for example, Anthony Giddens, who defines patriarchy as a 'system of domination of men over women within the family, as well as in a wider context of other social institutions.' 'Pol, patriarkhat i razvitie kapitalizma,'Sotsiologicheskie issledovaniia No. 7 (1992): 135 140. Heidi Hartmann specifies that patriarchy is 'the system of male oppression of women,' that 'has a material base and in which there are hierarchical relations between men, and solidarity among them.' 'Capitalism, Patriarchy, and Job Segregation by Sex,' in Giddens and Held, eds., Classes, Power and Conflict: Classical and Contemporary Debates (Berkeley, 1982): 137-169. A similar approach is taken by Sylvia Walby in her book Theorizing Patriarchy (Oxford, UK: 1990). It should also be noted that not all Russian rulers were male. For a more detailed examination of the effects of female rule on the society, see Richard Wortman, 'The Russian Empress as Mother,' in The Family in Imperial Russia, ed. by David L. Ransel (Urbana, 1978): 60-74.

${ }^{9}$ Of course, the use of the family metaphor in political discourse is not uniquely Russian. See, for example, George Lakoff's Moral Politics: How Liberals and Conservatives Think (Chicago: University of Chicago Press, 2010).

${ }^{10}$ Notably, this proverb (supplied with an exclamation point at the end) is included in a 2015 popular edition of Domostroi, a medieval collection of rules for a Russian household that includes instructions on such matters as how to pickle cabbage, how to rear children, how to pray, and how to arrange mowed hay, etc., indicating the persistence of this traditional view. T.N. Tereshchenko, ed., Domosroi: kak ustroit' svoi byt bogougodno, a zhizn' sviato (Moskva, 2015): 13.

${ }^{11}$ See 'Vsepoddanneishie pis'ma.' Severnaia pchela [St. Petersburg] 31 May 1863: 658. Print.

${ }^{12}$ S. Markov, Pokinutaia tsarskaia sem 'ia 1917-1918: Tsarskoe selo-Tobol'sk-Ekaterinburg (Ripol Klassik, 2013): 37.

${ }^{13}$ See K.A. Solov'ev, Khoziain zemli russkoi?: samoderzhavie i biurokratiia v epokhu moderna (Moskva, 2017).

${ }^{14}$ Richard Anderson, 'Metaphors of Dictatorship and Democracy: Change in the Russian Political Lexicon and the Transformation of Russian Politics,' Slavic Review 60, no. 2 (2001): 312-335. 
${ }^{15}$ Following Vladimir Putin's reelection as the President of Russian Federation in 2018, Albir Krganov, the Mufty of Moscow and the Head of the Central Spiritual Congregation of Muslims of Russian Federation, called him the father of the people of Russia: 'For Russia is our big family in which we've lived for many centuries. And the head of the state is in some measure... is our father, manager, leader of a multinational people of Russia.' See 'Muftii Moskvy nazval Putina otzom rossiiskogo naroda,' Interfax Religion <https://cursorinfo.co.il/muftij-moskvy-nazval-putina-ottsom-rossijskogonaroda/> Accessed Jun. 1, 2018.

${ }^{16}$ See Iurii Lotman, 'The Poetics of Everyday Behavior in Eighteenth-Century Russian Culture,' The Semiotics of Russian Cultural History (1985): 67-94.

${ }^{17}$ A.V. Chayanov, The Theory of Peasant Economy (Homewood, Il., 1966): 54. For more information on the work of zemstvos as elected self-governing institutions, which managed local economic affairs within various districts of the Russian Empire between 1864 and 1918, see Terence Emmons and Wayne S. Vucinich, The Zemstvo in Russia: an Experiment in Local Self-government (Cambridge, 1982)

${ }^{18}$ See William G. Wagner, Marriage, Property and Law in Late Imperial Russia (Oxford, 1994): 81.

${ }^{19}$ Stephen Lovell, 'From Genealogy to Generation: The Birth of Cohort Thinking in Russia,' Kritika: Explorations in Russian and Eurasian History 9, no. 3 (Summer 2008): 567-594.

${ }^{20}$ Lewis S. Feuer, The Conflict of Generations; the Character and Significance of Student Movements (New York, 1969): 99.

${ }^{21}$ The idea of continuity was first suggested by Turgenev himself, when in the preface to his 1879 collected edition of his major works he stated the following: 'I wished to give those of my readers, who will take upon themselves the task of reading these six novels one after another, an opportunity to verify the justice of those critics who reproached me for changing the direction that I once chose... [O]ne can sooner reproach me for being excessively consistent and for the straightforwardness of my direction [...] I strived, as much as I had the strength and the skill, to conscientiously and objectively depict [...] 'the body and pressure of time' and [the] quickly changing physiognomy of Russian people of the cultured class [...] I dare think that the readers will not doubt the sincerity and uniformity of my aspirations.' I.S. Turgenev, Polnoe Sobranie Sochinenii, vol. 12 (Moskva, 1966): 303.

${ }^{22}$ On January 2, 1829, adoption of illegitimate children was banned in Russia. In 1858, a change in the law was introduced that allowed exceptions 'in special, extenuating circumstances': parents had to be subsequently married and the petitioner had to demonstrate special merit in the eyes of the state. The parents also had to proye that the child was not conceived in adultery. 'For this reason, the legalization was possible only for some people, and their fate depended entirely on a monarch's grace.' S.V. Zaitseva, 'Uzakonenie vnebrachnykh detei v Rossiiskoi imperii v kontse XIX nachale XX v.,' Vestnik LGU im. A.S. Pushkina, no. 3 (2010): 110-116. Also see Georgii Gachev, Natsional'nye obrazy mira (Moskva, 1988): $148-9$

${ }^{23}$ Although at the present I focus on a male protagonist, Turgenev's female characters deserve a special consideration. See, for example, Dale E. Peterson, 'From Russia With Love: Turgenev's Maidens and Howells's Heroines,' Canadian Slavonic Papers / Revue Canadienne des Slavistes 26, no. 1 (March 1984): 24-34. Joe Andrew, 'Ivan Turgenev and the "New Eve," in Women in Russian Literature, 1780 1863 (London, 1988): 112-154. El'vira Nikolaevna Akimova, 'Lingvokul'turnyi tipazh "turgenevskaia devushka" v romane I.S. Turgeneva "Rudin," I.S. Turgenev: ruddkaia i natsional'nye literatury (2013): 34-41. Ekaterina Taratuta, 'Ironiia I skepsis v izobrazhenii zhenshchin-emancipee (na primere sochinenii I.S. Turgeneva),' in Potolok pola: Sb. nauchnykh i publitsisticheskikh statei, ed. by T. Barchunovoi (Novosibirsk, 1998) <http://www.a-z.ru/women/texts/taratr.htm> Accessed June 18, 2018. It should be noted, however, that women who joined the Going to the People movement were not free from the effects of the family metaphor. '[T] hey strove constantly to prove their dedication, loyalty, and self-sacrifice. They pleaded to be transferred to the most dangerous assignments. On the one hand, these activities had traditionally been coded as "male." Yet at the same time they showed a dedication to the "family" of revolutionaries that perpetuated female stereotypes.' Elizabeth A. Wood, 'The Woman Question in Russia: Contradictions and Ambivalence,' in A Companion to Russian History, ed. by Abbot Gleason (Chichester, 204): 353-367. 
${ }^{24}$ Frank Friedeberg Seely, 'The Heyday of the "Superfluous Man” in Russia,' The Slavonic and East European Review 31, no. 76 (December 1952): 92-112.

${ }^{25}$ A.G. Bocharov, Sovremennyi semeino-bytovoi roman (Moskva, 1978): 6. It appears that the genre of the family novel is ostensibly underrepresented in Russian literature not because Russian authors are not interested in families, but because of the heavy metaphorical weight of the family concept in the Russian context.

${ }^{26}$ Ivan Turgenev, Virgin Soil, trans. Michael Pursglove (Richmond, 2015): 19.

${ }^{27}$ The play also in some way foreshadows Nezhdanov's own relationship with Marianna, who leaves the home of her guardian with Nezhdanov but cannot marry him.

${ }^{28}$ The practice of sham marriages as a means for young women to start an independent life became widespread in the 1860s. In some cases, the spouses fell in love with each other later; in other cases, the relationship remained distant. See Rodigina and Eklof, 90-102.

${ }^{29}$ Avram Yarmolinsky, Road to revolution, A century of Russian radicalism (New York, 1959): 170.

${ }^{30}$ For a more detailed analysis of the term and its use, see Richard Pipes, 'Narodnichestvo: A Semantic Inquiry,' Slavic Review 23, no. 3 (1964): 441-58.

${ }^{31}$ By other estimates, over four thousand people were initially involved in the investigation of 'The Trial of 193.' See T.A. Soburova and Ben Eklof, Druzhba, sem'ia, revoliutsiia: Nikolai Charushin $i$ pokolenie narodnikov 1870-kh gg. (Moskva, 2016): 121. Vera Broido a different set of numbers: 'by the end of the year [1873] the number of arrests mounted to 1,600. According to Count Pahlen 770 persons (612 men and 158 women) were finally selected for trial, a further 265 were kept in detention, another 452 were released but kept under observation, and 53 suspects were never found. Eventually, only 193 accused were tried in the Great Trial ... But far greater numbers were exiled without trial.' Vera Broido, Apostles Into Terrorists (New York, 1977): 96.

${ }^{32}$ Revoliutsionery 1870-kh gg. Vospominaniia uchastnikov narodnicheskogo dvizheniia v Peterburge (Leningrad, 1986): 154, quoted in Ben Eklof and T.A. Saburova, A generation of Revolutionaries: Nikolai Charushin and Russian Populism from the Great Reforms to Perestroika (Bloomington, 2017): 46.

${ }^{33}$ By the 1870 s, when the intelligentsia began to include not only the nobility but people of diverse ranks, this description to some extent could apply to children of merchants and the clergy. See Mokshin, 62. N.K. Mikhailovskii, one of the leaders of the Russian populist movement, stated: 'if I, an "intellectual" person, have realized that my intellect and all the pleasures connected to it have been bought at the price of "sweat of many," then how should I act? I cannot turn away from intellectual pleasures, but neither can I claim that their origin is sinless.' N.K. Mikhailovskii, Polnoe sobranie sochinenii v 10 tomakh, vol. 7 (St. Peterburg, 1906-1913): 135, quoted in Mokshin, 62.

${ }^{34}$ Anne Pedler, 'Going to the People. The Russian Narodniki in 1874-5,' The Slavonic Review 6, no. 16 (1927): 133.

${ }^{35}$ Ruth Perry, Novel relations: the transformation of kinship in English literature and culture, 17481818 (Cambridge, 2004): 4.

36 V.A. Nedzvetskii, I.S. Turgenev: Logika tvorchestva i mentalitet geroia (Moskva, 2011): 187.

${ }^{37}$ Paul Conner, 'Patriarchy: Old World and New,'American Quarterly 17, no. 1 (1965): 48. Also see Anderson, Metaphors of dictatorship and democracy.' For a general discussion of the use of family metaphors in politics, see George Lakoff, Moral Politics: How Liberals and Conservatives Think (Chicago, 2002). Also see Gordon S. Wood, The Radicalism of the American Revolution (Vintage, 2011): 145-168. For a commentary on more recent history, see Sara Hayden's 'Family Metaphors and the Nation: Promoting a Politics of Care Through the Million Mom March,' Quarterly Journal of Speech 89, no. 3 (2003): 196-215. Allison M. Prasch, 'Maternal Bodies in Militant Protest: Leymah Gbowee and the Rhetorical Agency of African Motherhood,' Women's Studies in Communication 38, no. 2 (2015): 187205.

${ }^{38}$ Marc Raeff, 'The People, the Intelligentsia and Russian Political Culture,' Political Studies XLI (1993), 98n9. Also see Martin Malia, 'What Is the Intelligentsia?' in The Russian Intelligentsia, ed. Richard Pipes (New York, 1961): 1-18. 
${ }^{39}$ Daniel R. Brower, 'The Problem of the Russian Intelligentsia,' Slavic Review 26, no. 4 (Dec., 1967): 638-647. Also see, Esther Kingston-Mann, 'In the Light and Shadow of the West: The Impact of Western Economics in Pre-Emancipation Russia,' Comparative Studies in Society and History 33, no. 1 (1991): 86-105 and Susan Morrissey, Heralds of Revolution: Russian Students and the Mythologies of Radicalism (Oxford, 1998).

${ }^{40}$ The complexity of this term has been discussed numerous times. See, for example, Vekhi: Intelligentsiia v Rossii. Sborniki statei 1909-1910, ed. by N. Kazakova (Moskva, 1991). G.N. Mokshin, Ideologi legal'nogo narodnichestva o russkoi intelligentsii (Voronezh, 2007). A.A. Shiriniants, 'Is istorii samoopredeleniia grazhdanskogo obshchestva v Rossii: raznochinnaia intelligentsia 1860-1870 gg.,' Vestnik Nishegorodskogo universiteta im. N.I. Lobachevskogo, no. 6 (2014): 97-104. A.E. Varpetian, 'Russkaia intelligentsia i istoricheskaai traditsiia: P.B. Struve i P.N. Miliukov,' Veche. Zhurhal russkoi filosofii i kul'tury, no. 28 (2016): 28-35.

${ }^{41}$ S.N. Bulgakov, 'Geroism i podvizhnichestvo,' in Vekhi: Intelligentsiia v Rossii. Sborniki statei 1909-1910 (Moskva, 1991): 45.

${ }^{42}$ Petr Struve, 'Intelligentsiia i revoliutsiia.' $<$ http://www.vehi.net/vehi/struve.html $>$ Accessed May 15, 2018. Although Turgenev was very effective in portraying the Russian intelligentsia in his novels, strictly speaking he did not belong to the intelligentsia himself. He never participated in political activism and especially towards the end of his life disappointed Russian radicals. See Leonard Shapiro, 'The PreRevolutionary Intelligentsia and the Legal Order,' in The Russian Intelligentsia, ed. Richard Pipes (New York, 1961): 19-31.

${ }^{43}$ Marc Raeff, Origins of the Russian Intelligentsia; The Eighteenth-Century Nobility (New York, 1966): 19.

${ }^{44}$ See, for example, James Hassell, 'Implementation of the Russian Table of Ranks During the Eighteenth Century,' Slavic Review 29, no. 2 (1970): 283-95. Also see Walter M. Pintner, 'The Social Characteristics of the Early Nineteenth-Century Russian Bureaucracy,' Slavic Review 29, no. 3 (1970): 429-43.

${ }^{45}$ These requirements did not apply to the members of the royal family. Iurii Lotman, Besedy o russkoi kul'ture: Byt i traditsii russkogo dvorianstva (XVIII—nachalo XIX veka), (Sankt-Peterburg, 2017): 32-3.

${ }^{46}$ Slavophiles and Westernizers were two loosely defined ideological groups that came to the fore in mid-nineteenth century. Both of them sought the most optimal course for Russia's development, were in favor of abolition of serfdom through government-led reforms, criticized authoritarianism, vied for the freedom of speech and religion, and opposed social transformation by way of revolution; however, they differed in the fundamentals. As Paul Bushkovich puts it, Westernizers were 'liberal and radical' admirers of Peter, whereas Slavophiles were 'admirers of Russian tradition' and Peter's 'detractors.' Paul Bushkovitch, A Concise History of Russia (New York, 2012): 95. V.G. Shchukin notes that both Slavophiles and Westernizers came as a result of a synthesized experience 'of two opposing ways of Russian life,' and both of them were equal in their utopianism. V.G. Shchukin, 'Slaviano-fil'stvo i zapadnichestvo: Sotsiokul'turnye modeli,' Ocherki russkoi kul'tury XIX veka, vol. 5 (Moskva, 2005): 1458. Also see N.I. Tsimbaev, 'Liberaly sorokovykh godov,' in Ocherki russkoi kul'tury XIX veka, Obshchestvennaia mysl', vol. 4 (Moskva, 2003), 164-196.

${ }^{47}$ Nikolai Berdiaev, Aleksei Stepanovich Khomiakiv (Paris, 1997).

$<$ http://www.vehi.net/berdyaev/khomyakov/06.html> Accessed Oct. 20, 2017. Emphases added.

${ }^{48}$ V.A. Lukina, "Nov" v zerkale russkoi kritiki: Turgenev—chitatel' pervykh otklikov na roman,' Turgenevskii ezhegodnik 2013 goda (Orel: ORLIK, 2014): 21-32.

${ }^{49}$ Also see Budanova, N.F. 'Komentarii: I.S. Turgenev. Nov'.' In I.S. Turgenev. Polnoe sobranie sochinenii i pisem v tridtsati tomakh, vol. 9 (Moskva: Nauka, 1982): 479-559.

${ }^{50}$ Burenin's article was signed with a penname. See Tor, 'Novyi roman I.S. Turgeneva.' Novoe vremia [St. Petersburg] 6 Jan. 1877: 1-3. Print.

${ }^{51}$ Meshchersky, V.P. 'Dnevnik.' Grazhdanin [St. Petersburg] 7 (19) Feb. 1877: 142, 143. Print. 